\title{
Estimation of Subsidence in Po Delta Area (Northern Italy) by Integration of GPS Data, High-Precision Leveling and Archival Orthometric Elevations
}

\author{
Massimo Fabris, Vladimiro Achilli, Andrea Menin \\ Department of Civil, Environmental and Architectural Engineering, University of Padova, \\ Padova, Italy \\ Email: massimo.fabris@unipd.it, vladimiro.achilli@unipd.it, andrea.menin@unipd.it
}

Received 6 March 2014; revised 2 April 2014; accepted 28 April 2014

Copyright (C) 2014 by authors and Scientific Research Publishing Inc. This work is licensed under the Creative Commons Attribution International License (CC BY). http://creativecommons.org/licenses/by/4.0/

\section{(c) (i) Open Access}

\begin{abstract}
Subsidence in a deformation area can be measured in various ways, examples being conventional high-precision leveling, differential InSAR and multi-temporal GPS surveys. Integration of methods can improve results, and is crucial to extract high-precision data. In particular, orthometric and ellipsoid elevations, surveyed at different moments in time, can be compared to yield information on vertical movements when geoid anomalies are known. However, a data checking procedure must be applied if archival orthometric elevations are used, because long-term measurements for many historical benchmarks may have been lost and/or replaced with other points, but at different elevations. This type of checking can be carried out over an area without gravimetric anomalies by modeling geoid undulations and vertical displacements in the time-span used for analysis, excluding points with anomalous values. This procedure was tested and applied in the Po Delta area (northern Italy), historically subject to high subsidence rates: the leveling benchmarks of 1983 were measured with the GPS technique in 2008. After checking of archival data and transformation from ellipsoid to orthometric elevations, comparisons of the same points and interpolations on the study area provided a subsidence map for the 1983-2008 period.
\end{abstract}

\section{Keywords}

Subsidence, Po Delta, Spirit Leveling, GPS, Local Geoid Modeling 


\section{Introduction}

Ground deformation in areas subject to vertical displacements can be studied by comparing the orthometric elevations of benchmark leveling measured at different times. This technique supplies high-precision data, but the measurements require long timings and are expensive to monitor vertical deformations. In the past, this method was the only one available, yielding high-precision data for assessment of land subsidence along the northern Adriatic coastland.

It was only in the 1990s that GPS (Global Positioning System) methods, both continuous (CGPS) and differrential (DGPS), began to be used for measuring sufficiently accurate ground movements, with the result that many permanent GPS stations, which acquire data continuously, are now available [1]. Many GPS points have also been surveyed on ground which, when measured subsequently, yield the same differences: in this case, the precision with which GPS elevation values are determined must be estimated with care. Again since the 1990s, space-borne observation techniques based on Synthetic Aperture Radar (SAR) interferometry have also been used to detect subsidence and uplift along the Veneto coastland. First differential InSAR (DInSAR) and later Interferometric Point Target Analysis (IPTA) have been applied to measure and map displacements occurring since 1992, when SAR data first became available [2]. Both GPS and SAR data can now provide analyses covering the last twenty years, but integration with conventional high-precision leveling data is not simple, due to differences in reference systems. Ellipsoid and orthometric elevations can be compared when the data refer to the same surface, when the geoid heights of the analysed area are known, and ellipsoid (GPS) elevations can now be transformed into orthometric ones [3] [4]. GPS elevations applied to geoid heights, for direct comparisons between orthometric (conventional leveling) and transformed orthometric (GPS) elevations, performed at different times on the same benchmark, yield data on vertical displacements in the time-span in question. Thus, the congruence of elevation of the same benchmark can be checked over long periods of time. Archival leveling benchmarks, measured in the past but not repeated recently, must be verified, to ascertain that GPS measurements are performed on the same archival benchmark: only in this case can the two methods be integrated. Other techniques, such as aerial digital photogrammetry and laser scanning, are useful for measuring vertical movements by comparisons between DTMs (Digital Terrain Models) acquired on the deformation area at different moments in time. Photographic archives, which are available for the last 70 - 80 years, are also an important source of historical data, enabling the ground surface to be modeled on a local scale over some decades. Historical images can be processed by archival photogrammetry, yielding multi-temporal metric information of the study area [5]-[10]. However, these methods are only useful when the expected displacements are of the order of $50 \mathrm{~cm}$ or more, due to problems of data resolution and technical accuracy [11]-[13].

In this work, comparisons between orthometric and ellipsoid elevations are used to evaluate the subsidence of the Po Delta area in the Veneto Region (northern Italy; Figure 1) for the period 1983-2008, with expected deformations of a few tens of centimeters. In this area, subsidence was monitored by GPS in 2008 on archival benchmarks and compared with elevations measured in 1983. In addition, due to the long time-span (25 years), a procedure to verify the 1983 orthometric elevations was performed, because some benchmarks may have been lost and replaced with other points at non-homogeneous elevations. Subsequently, these data were integrated with the orthometric elevations of conventional leveling lines measured in 1984 and 2005.

\section{State-of-the-Art of Subsidence in Northern Italy and Po Delta}

Long-term natural subsidence is mainly the result of deep tectonics, glacial cycles and geodynamic movements [14]-[19]. Carminati et al. [14] indicated the downflexure of the Adria plate as one cause of movement, at a maximum rate of $2.5 \mathrm{~mm}$ /year. The possible effects of tectonic activity along the northern Apennine thrust front buried under quaternary sediments was thoroughly discussed in [20]. More sophisticated measurements now show that the recent deformation pattern of the Apennine belt and Po Plain is due to the northward movement of the Adria plate [21].

Subsidence in the study area has been periodically monitored by leveling measurements since 1897 [22], and comparisons between the leveling lines for the period 1897-1957 indicate subsidence rates of a few millimeters per year. Total subsidence dramatically increased in the second half of the $20^{\text {th }}$ century, when economic development in the region almost quadrupled the amount of groundwater extracted for industry, agriculture and domestic purposes, compared with previous years [23] [24]. The most recent dataset, collected by the regional authorities, indicates that subsidence in the last years of the $20^{\text {th }}$ century was in some areas at least one order of 

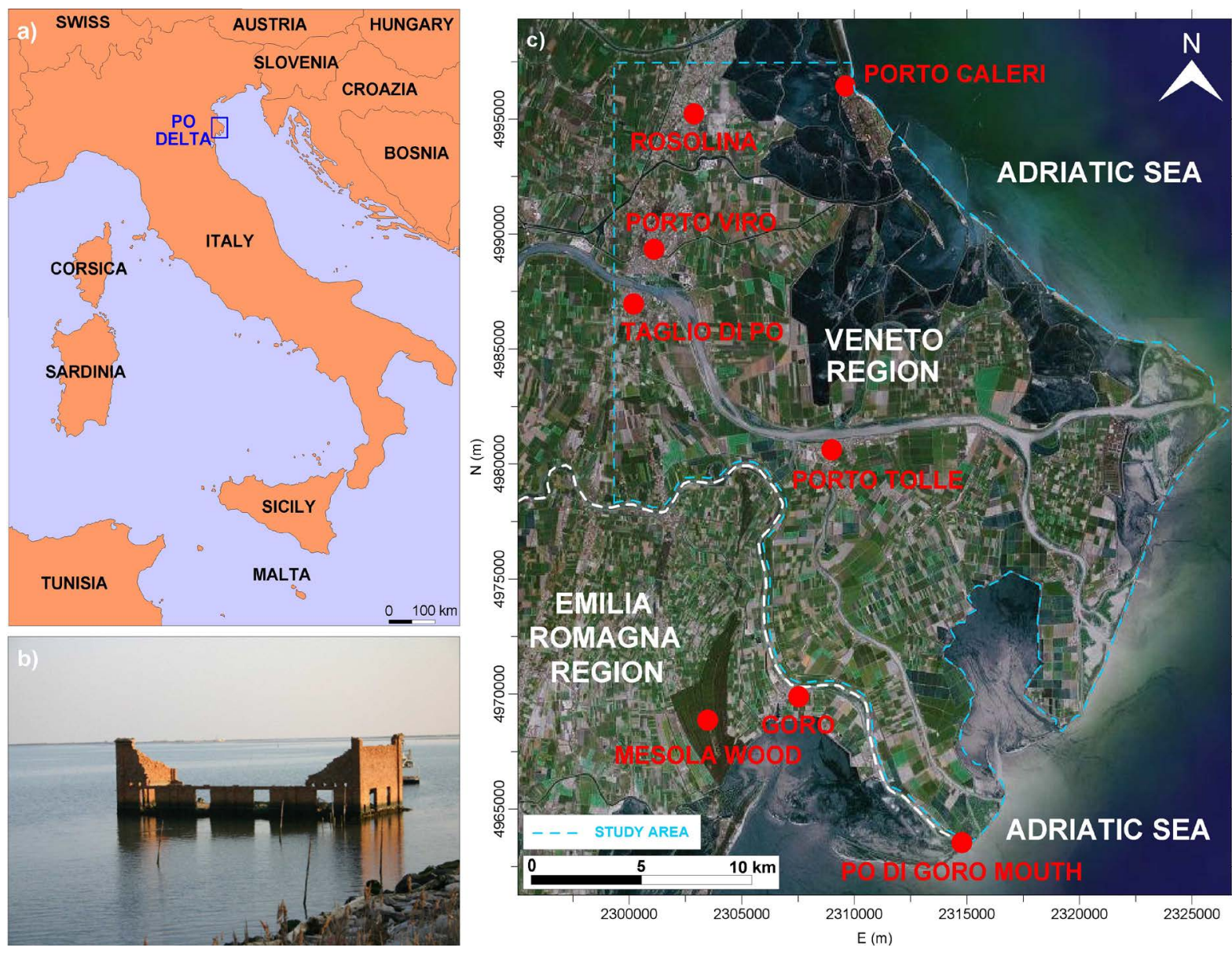

Figure 1. (a) Location of Po Delta area; (b) Effects of subsidence, also linked to changes in coastline, causing submergence of large areas; (c) Regional boundaries and indication of study area, of about $600 \mathrm{~km}^{2}$ (dashed cyan line).

magnitude higher than that produced by natural geodynamic and geological processes.

Along the Veneto coastland, human activities-pumping water and gas from underground reservoirs-still creates many problems in inhabited areas only a few meters above sea level, since they are continuously subject to frequent flooding [25] [26]. One clear-cut example is the ancient city of Venice, which lies in a barrier island lagoon system just north of the Po Delta and is regularly subject to flooding by high tides. Both natural and anthropogenic land subsidence and eustasy in the northern Adriatic have caused $23 \mathrm{~cm}$ of relative land subsidence, with respect to the mean sea level over the last 100 years [15]-[18] [27]-[29]. Spirit leveling and CGPS and DInSAR methods, applied since 2000, have shown that subsidence no longer occurs in the center of Venice and in its industrial zone, but is still ongoing in the northern and southern lagoons and bordering land [30] [31]. Baldi et al. [32], using CGPS method, provides data on maximum vertical displacements of some $\mathrm{mm} / \mathrm{year}$ at Modena, Reggio Emilia, Bologna, Ravenna and the Po Delta.

Deltas and their estuaries have great ecological and economic value and support both high populations and extensive agriculture [33]. The influence of the sea (waves, storm surges, flooding) and the reduction of river sediment supplies, due to natural processes and human interventions, make the most important Mediterranean deltas (Nile, Rhone, Po and Ebro) highly vulnerable to rises in sea level [34].

The Po Delta covers an area of about $400 \mathrm{~km}^{2}$, extends seaward for about $25 \mathrm{~km}$ (Figure 1) [35], and is characterized by a complex multi-aquifer freshwater system [36]. Subsidence is an important factor in the altimetry of the Po Delta. It has both natural and artificial origins: natural, caused by soil lowering due to the compaction of lithological layers of "young" soil and oxidation of peat, and artificial, due to draining of wetlands, land reclamation and, in particular, the extraction of methane water, which was carried out with the greatest intensity from the 1940s until 1961, when the Italian government suspended extraction in the area [37]. Natural subsi- 
dence has been estimated at 1 - 2 mm/year in the Delta. Reclamation has also caused local subsidence, but cannot completely explain the falling rates over the last 60 years [38]-[44].

Due to the significant economic impact of subsidence, vertical movements have been monitored since 1950 [45] by repeated high-precision leveling, undertaken by the IGMI (Istituto Geografico Militare Italiano) and later by other local authorities, companies and institutions [22] [39] [44] [46]-[49]. Caputo et al. [39] and Borgia et al. [47] reported a maximum subsidence rate of $250 \mathrm{~mm} / \mathrm{year}$ in the central part of the Po Delta for the period 1951-1957 and $180 \mathrm{~mm} /$ year between 1958 and 1962. Later, from 1962 to 1967, these rates fell to $33 \mathrm{~mm} /$ year, matching the progressive reduction of extraction [39] and to $37.5 \mathrm{~mm} /$ year from 1967 to 1974 [40]. These last data clearly show the benefits gained by halting extraction, begun in the late 1970s. In subsequent years, the subsidence rate decreased, although the actual observed subsidence in some areas is at least one order of magnitude higher than that due to natural processes. The GPS technique has more recently been used to integrate conventional leveling with episodic and continuous measurements on spirit leveling lines [50]. Recent studies have shown that subsidence, although reduced, is still ongoing [44] [51]-[54]. Most of the Po Delta area now lies below sea level, sometimes by as much as 6 - 8 meters, and subject to flooding of river branches and other water courses. Combined subsidence, due to natural and anthropogenic causes [55] [56] may lead to serious environmental problems with consequent economic and social implications, especially as regards the mean sea level increase caused by global climate variations [57]. The irregular lowering of the terrain also definitely modifies the drainage of the secondary hydraulic network, and increases the rise in the salt wedge for many kilometers: for these reasons, constant monitoring of plano-altimetric changes throughout the Po Delta is essential in implementing territorial defense systems against flooding [14]-[17] [19] [27] [29] [33] [58].

\section{Available Data and GPS Measurements}

Vertical displacements in the Po Delta have been analysed with geodetic data acquired in the Po Delta in the last few decades. In particular, two conventional leveling lines were measured by the IGMI at different times: line 19 (with 10 benchmarks) at the northern boundary, and line 174_D2 (22 benchmarks) which follows the main stream of the "Po di Pila" in a west-east direction, in the center of the Delta. Line 19 was measured in 1950, providing long-term data over the same benchmarks, although some points have been lost in the meantime. Line 19 also marginally involved the study area. Unfortunately, spirit leveling was used to measure line 174_D2 only in 1978, 1984 and 2005.

As regards the accuracy of data, the leveling measurements of the above periods were double run in the flat Delta plain, to exclude the possibility of serious systematic errors affecting leveling [59] [60]. They indicate an accuracy of a few $\mathrm{mm}$ per $\mathrm{km}$, corresponding to an accuracy of a few $\mathrm{cm}$ for elevations of benchmarks separated by distances of up to $20 \mathrm{~km}$, as in this study (Figure 2). This estimate may be considered rather pessimistic of their true uncertainty level, because measurements were double run and the possibility of errors is therefore low.

Comparison of the orthometric elevations of the same benchmarks measured at different time yielded information on vertical movements (Figure 2). Throughout the dataset, point elevations decreased, mainly in the period 1950-1970, when the slope of the straight lines was greater. This effect was simultaneous with or slightly delayed with respect to the most intense phase of methane extraction [37] [39] [47] [52]. In the last period, 1970-2005, after extraction ceased, the phenomenon was still not exhausted [61]. The differences measured in the various periods are also certainly greater than the accuracy of this survey.

Other archival orthometric elevations of benchmarks from the Veneto Region regard data used to produce the regional CTR (Carta Tecnica Regionale), scales 1:5000 and 1:10,000, from the 1983 photogrammetric flight over the region. The maximum distance between benchmarks is about $40 \mathrm{~km}$, providing an estimate of accuracy double that of previous measurements $(\mathrm{a}$ few $\mathrm{cm}$ ).

The 1983 regional benchmarks were well distributed over the area, but site descriptions were missing or not available due to lack of data. The GPS campaign of February 2008 measured the position of regional and/or IGMI benchmarks: double-frequency Leica GPS Systems 1200 were used and the survey was performed in static mode at a sampling rate of $15 \mathrm{~s}$ and acquisition time of $60 \mathrm{~min}$ (elevation mask $15^{\circ}$ ). Benchmarks well distributed in the analysed area were chosen, and their points were selected to permit nearly ideal conditions (e.g., unobstructed horizon view, avoidance of multipath effect). As some of the 1983 benchmarks could no longer be directly measured, points very close to the old ones were recorded (usually no more than a few meters away). Elevation differences between the old points and the new GPS ones were then measured twice with a spirit level 

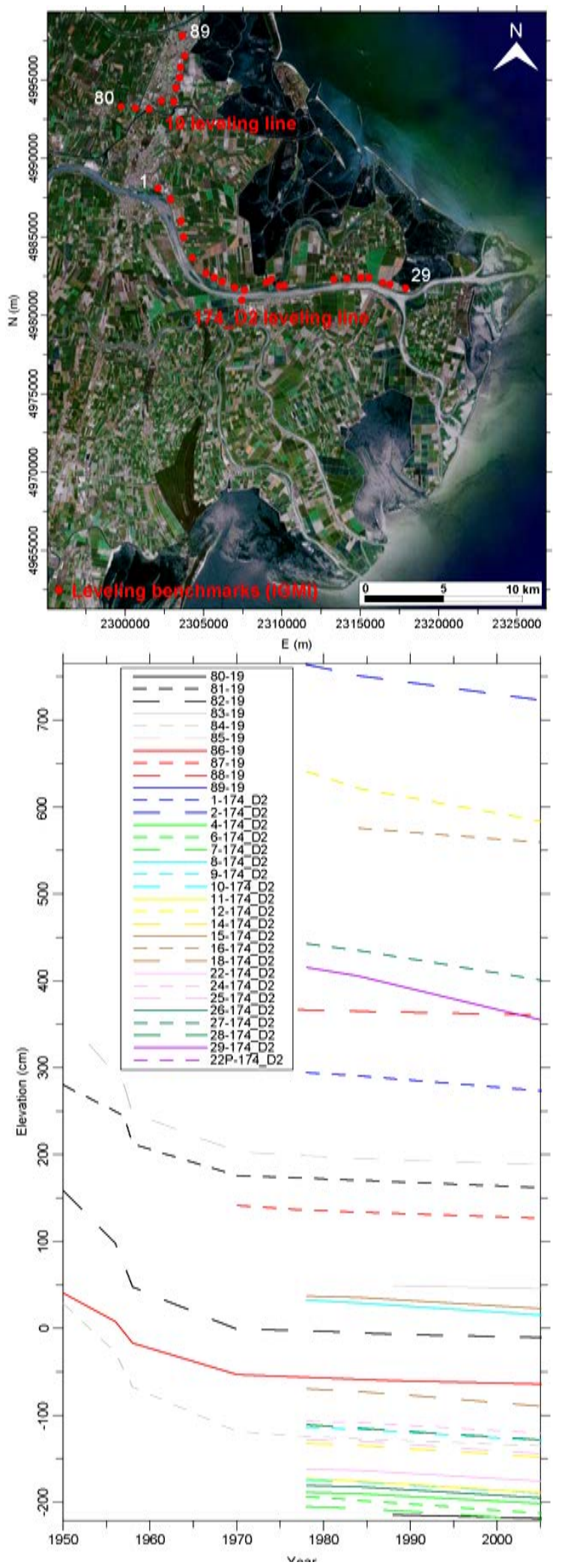

Figure 2. Location of two leveling lines (nos. 19 and 174_D2) measured by IGMI: analysis of elevations from surveys in different periods on same benchmarks show decreasing values for whole dataset (mainly in period 1950-1970). Colors: elevation trends for each benchmark of above leveling lines. 
and a staff; the latter is accurate to within $2 \mathrm{~mm}$.

Some points on the Veneto GPS network planned and measured in 2006 were used as reference stations (masters), and baselines with distances of less than 6 - $7 \mathrm{~km}$ were measured. At the end of the campaign, GPS data of 43 leveling benchmarks of the 1983 orthometric elevations were obtained. The data were processed by Leica Geo Office software, yielding the coordinates of the UTM-WGS84 reference system. The ellipsoid heights of the 1983 benchmarks were subsequently obtained from the elevation differences between GPS points and benchmarks as deduced from spirit leveling. This last correction did not introduce any significant errors, as the difference in the geoid height of points up to a few meters and could be ignored for the purposes of this study. The technique used to compute GPS ellipsoid heights has a nominal accuracy (standard error) of $\sigma_{G P S}^{2}$ described by the following formula [62]:

$$
\sigma_{\text {GPS }}=0.6 \mathrm{~cm} \pm 0.5 \cdot S \mathrm{ppm}
$$

where $S$ is the distance in kilometers between master and rover receivers, up to $7 \mathrm{~km}$ in this case, giving a nominal value for $\sigma_{G P S} \cong 1 \mathrm{~cm}$. However, as real errors may be several times higher [63], a more realistic value was adopted, i.e., $\sigma_{G P S} \cong 5 \mathrm{~cm}$.

Since leveling and GPS data are uncorrelated, the error in the elevation of each individual benchmark, following the law of error propagation, is given by the following equation:

$$
\sigma^{2}=\sigma_{G P S}^{2}+\sigma_{\text {leveling }}^{2} \cong \sigma_{G P S}^{2}
$$

as the leveling error at very short distances is minimum (up to $1-2 \mathrm{~mm}$ ) relative to the error in height determination according to GPS. This procedure extracted double elevations (orthometric 1983 and ellipsoid 2008 values) for 43 benchmarks with $\sigma$ of about $5-6 \mathrm{~cm}$.

\section{The Methodology}

When geoid heights are known, the values of vertical displacements can be obtained with the following equation (Figure 3):

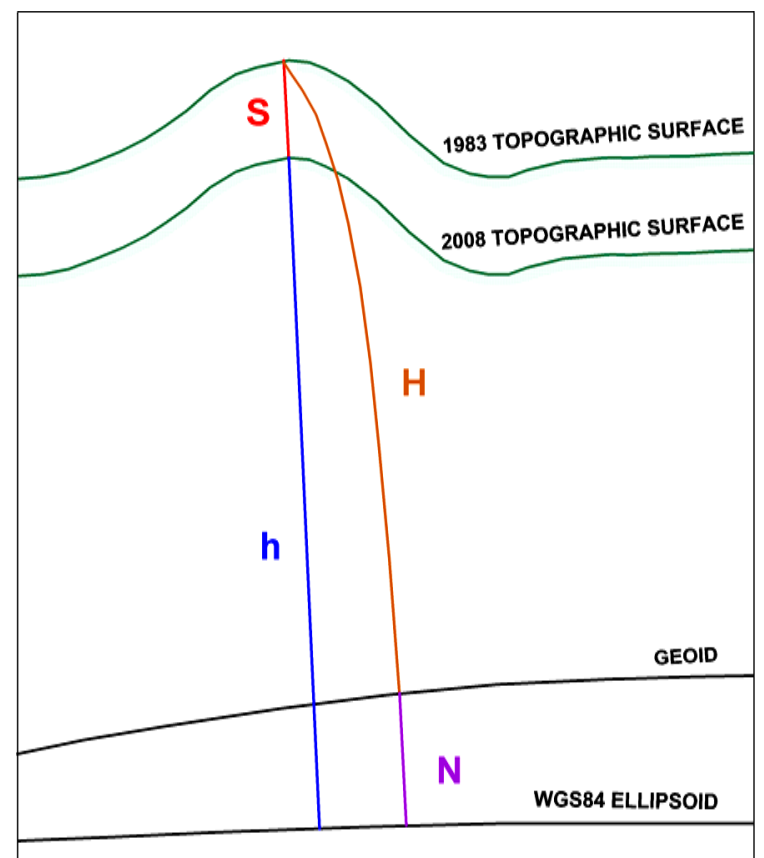

Figure 3. GPS leveling with subsidence: conventional equation of GPS leveling is integrated, to take into account changes occurring between surveys. $H$ : 1983 orthometric elevation; $h$ : 2008 ellipsoid elevation; $N$ : geoid height; $S$ : subsidence in period 1983-2008. 


$$
S_{1983-2008}+h_{2008} \cong H_{1983}+N
$$

where:

$S_{1983-2008}$ : vertical displacement between 1983 and 2008;

$h_{2008}$ : ellipsoid elevation measured with GPS in 2008;

$H_{1983}$ : orthometric elevation measured in 1983;

$N$ : difference between WGS84 ellipsoid and geoid (geoid height).

In this case, the conventional equation of GPS leveling [4] [62] must be corrected to take into account subsidence occurring in the period between the two surveys. $N$ values can be obtained from data on double elevations (surveyed at the same time) of many points uniformly located in the study area and interpolating the data or from gravimetric measurements. Subsequently, GPS surveys can yield the parameter $h_{2008}-N$ which, if the $H_{1983}$ of archival benchmarks are known, yields $S_{1983-2008}$ values. With this reasoning, we assume that ground subsidence affecting only some near-surface strata has no effect on geoid height $N$. This is a reasonable simplification: even in the Fennoscandinavian uplift, which expresses a large-scale effect in both space (mantle doming over a region of $1000-2000 \mathrm{~km}$ ) and in time (thousands of years), the rate of change in geoid height is one order of magnitude smaller than the rate of change in topography [64].

However, the equation is only correct in theory: in fact, over a period of 25 years, many human interactions have occurred in the territory, sometimes altering some benchmarks and replacing them with other points very close to the old ones, but at different orthometric elevations. In these cases, the 2008 ellipsoid elevations of points arising from unauthorised re-installations replacing the real 1983 benchmarks, now destroyed but previously often at different heights, and then at different orthometric elevations, were re-measured.

As described by Psimoulis et al. [62], this is the major source of errors in benchmarks, because non-homogeneous data are obtained. A procedure to evaluate the congruence of the 1983 orthometric elevations thus had to be applied. Due to the small area and no gravimetric anomalies are documented [65], the $N$ values must be homogeneous.

Some equations were tested to find the best surface allowing the $N-S_{1983-2008}$ (i.e. $h_{2008}-H_{1983}$ ) parameter to be modeled. Due to territorial morphology and the absence of gravimetric anomalies, the shape of the geoid surface (geoid height) is close to an inclined plane in the analysed area, so that initially simple equations were tested and the data were later improved with increasingly complex forms (until the second order of $N-S_{1983-2008}$ ). Testing was carried out near Chioggia, a few kilometers north-west of the Po Delta, for which coeval orthometric and ellipsoid elevations were available (spirit leveling and GPS data). The area is also characterized by the same morphology and geoid surface forms as the Delta. Twenty benchmarks with double elevations were used as control points over an area of about $80 \mathrm{~km}^{2}$, and 30 others were used as check-points to evaluate models precision. The benchmarks were located both inside (15) and outside (15) the interpolation area up to a distance of $10 \mathrm{~km}$, so that the extrapolation limits of the models could also be evaluated (Figure 4). These data had the same accuracy as those discussed above.

The following interpolation surfaces were analysed:

$$
\begin{gathered}
N=a_{1} X+a_{2} Y+a_{3} \\
N=b_{1} X+b_{2} Y+b_{3} X Y+b_{4} \\
N=c_{1} X+c_{2} Y+c_{3} X^{2}+c_{4} X Y+c_{5} Y^{2}+c_{6} \\
N=d_{1} X+d_{2} Y+d_{3} X^{2}+d_{4} X Y+d_{5} Y^{2}+d_{6} X^{2} Y+d_{7} X Y^{2}+d_{8} X^{2} Y^{2}+d_{9} \\
e_{1} X^{2}+e_{2} Y^{2}+e_{3} N^{2}+e_{4} X Y+e_{5} X N+e_{6} Y N+e_{7} X+e_{8} Y+N+e_{9}=0
\end{gathered}
$$

where:

$a_{i}, b_{i}, c_{i}, d_{i}, e_{i}$ : parameters;

$X Y$ : planimetric coordinates;

$N$ : geoid height.

The Kriging geostatistical method, IDW (Inverse Distance Weight) and RBF (Radial Basis Function) deterministic interpolation methods were also applied [66]-[72].

Twenty double-elevation control points were used to calculate parameters $a_{i}, b_{i}, c_{i}, d_{i}, e_{i}$ of models (1), (2), (3), (4) and (5) with the least-squares method. The $N$ values, obtained with the models used for the check-points, 


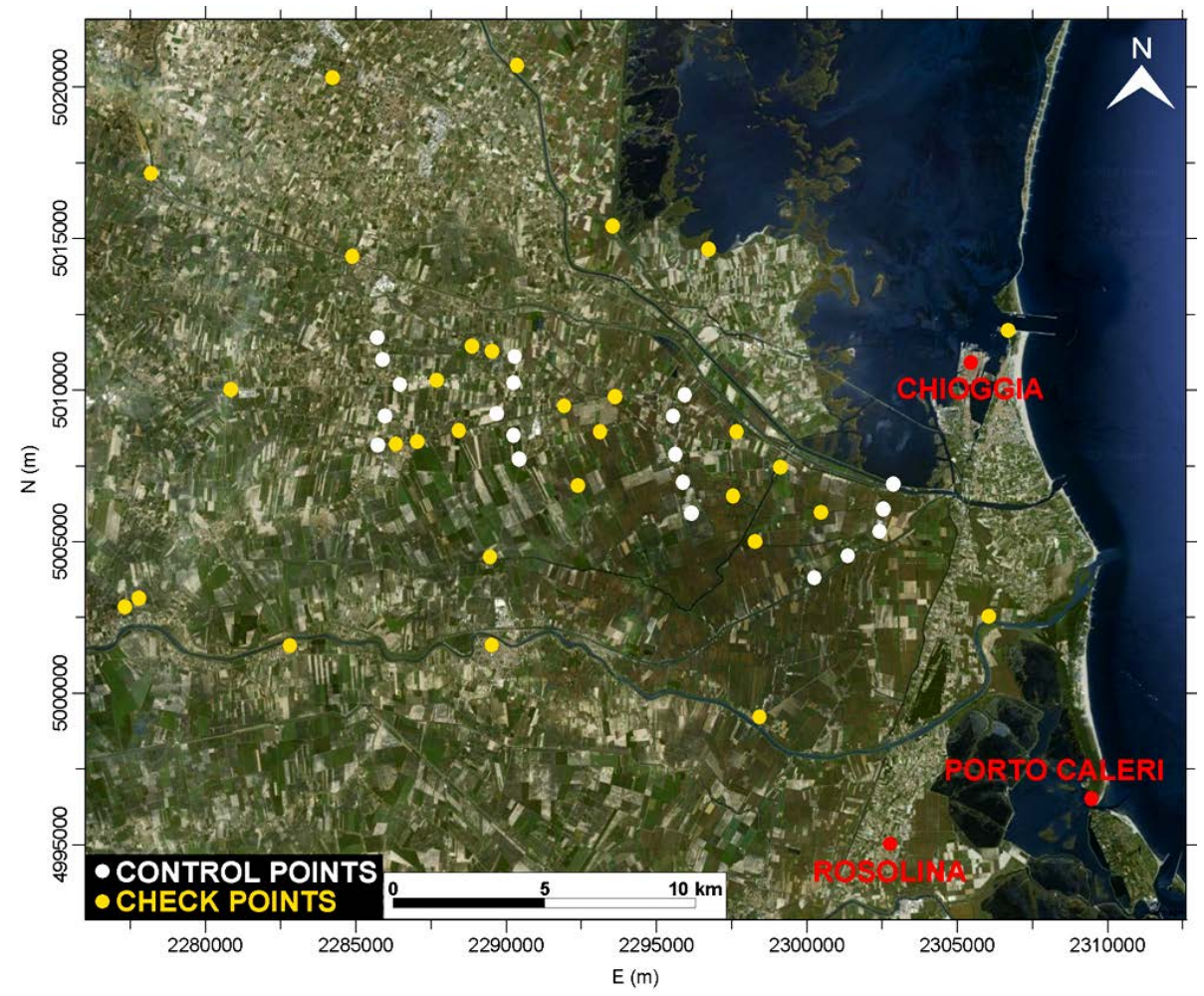

Figure 4. Tests area located NW of Po Delta (Veneto Region); 50 points of coeval double elevations: 20 benchmarks and 30 points (15 inside and 15 outside study area) used as checkpoints to evaluate precision of local geoid modeling and limits of surface extrapolation.

were then compared with the inner and outer measured check-points (Table 1).

Table 1 shows the most accurate data for the model obtained with Equation (5): on benchmarks about $10 \mathrm{~km}$ from the study area, the maximum difference between $N$ calculated and $N$ measured was $5.5 \mathrm{~cm}$. The data provided by quadratic surface (5), inside the study area, were also compared with Italian gravimetric geoid ITALGEO 2005, characterized by declared precision of about $4 \mathrm{~cm}$, and provided a mean of $-0.6 \mathrm{~cm}$ and standard deviation of $1.6 \mathrm{~cm}$. These data show that Equation (5) clearly represents the progress of $N$ and suggests using the surface for local modeling of $N-S_{1983-2008}$ values in the Po Delta area.

The orthometric elevation of the 1983 benchmarks was analysed by modeling the $N-S_{1983-2008}$ values: for interpolation, the best model obtained from the tests was used, corresponding to a second-order surface with nine parameters (5). Points with anomalous values (those exceeding a threshold of $3 \mathrm{~cm}$ in least-squares processing) can be removed.

Unfortunately, points with substantial relative differences in $S_{1983-2008}$ values are also removed during statistical processing. However, the gradients could later be recovered in the $h_{2008}-H_{1983}$ differences (with $H_{1983}$ correct) by GPS measurements. In this case, Equation (5) becomes:

$$
f_{1} X^{2}+f_{2} Y^{2}+f_{3} V^{2}+f_{4} X Y+f_{5} X V+f_{6} Y V+f_{7} X+f_{8} Y+V+f_{9}=0
$$

where:

$f_{i}:$ nine parameters;

$X Y$ : planimetric coordinates;

$V=N-S_{1983-2008}$ (i.e. $\left.h_{2008}-H_{1983}\right)$ value.

The analysis required excluding 11 out of 43 points (as there were benchmarks with anomalous geoid heights and/or high differential vertical displacements in the period 1983-2008). However, the other 32 points were uniformly distributed over the Delta. The 11 previously excluded points were then assigned the orthometric elevations of 1983, according to the surfaces calculated on the check-points. At the end of the procedure, 43 benchmarks with 1983 and 2008 corrected orthometric elevations were available. 


\section{Discussion}

The vertical displacements obtained with the procedure described above were integrated with data from spirit leveling measurements (32 benchmarks), interpolated and extrapolated linearly to yield a dataset for the same 1983-2008 period. The 75 differences in the points of the study area (Figure 5(a)) were interpolated according to the IDW deterministic interpolation method, which is able to intercept subsidence peaks which Equation (5) cannot record adequately. In this way, a 10 -m grid size was extracted by processing about $5 \times 10^{6}$ points; only the area enclosed by benchmarks was analysed, as the characteristics of the interpolation method provides unreliable data outside the study area (Table 1) (Figure 5(b)).

The map shows most vertical displacements (30 - 35 cm in 25 years) in the south-eastern part of the Po Delta,

Table 1. Comparisons between $N$ values calculated with various models and data measured at check-points inside and outside study area.

\begin{tabular}{ccccc}
\hline \multirow{2}{*}{ MODEL } & \multicolumn{2}{c}{ INNER CHECK-POINTS } & \multicolumn{2}{c}{ OUTER CHECK-POINTS } \\
\cline { 2 - 4 }$(1)$ & Average $(\mathrm{m})$ & St. Dev. $(\mathrm{m})$ & Average $(\mathrm{m})$ & St. Dev. (m) \\
$(2)$ & -0.006 & 0.021 & -0.016 & 0.144 \\
$(3)$ & -0.012 & 0.027 & -0.101 & 0.249 \\
$(4)$ & -0.015 & 0.032 & -0.391 & 0.225 \\
$(5)$ & -0.017 & 0.030 & -0.482 & 0.354 \\
Kriging & -0.002 & 0.007 & -0.013 & 0.045 \\
IDW & 0.026 & 0.026 & 0.083 & 0.084 \\
RBF & 0.031 & 0.032 & 0.119 & 0.178 \\
\hline
\end{tabular}
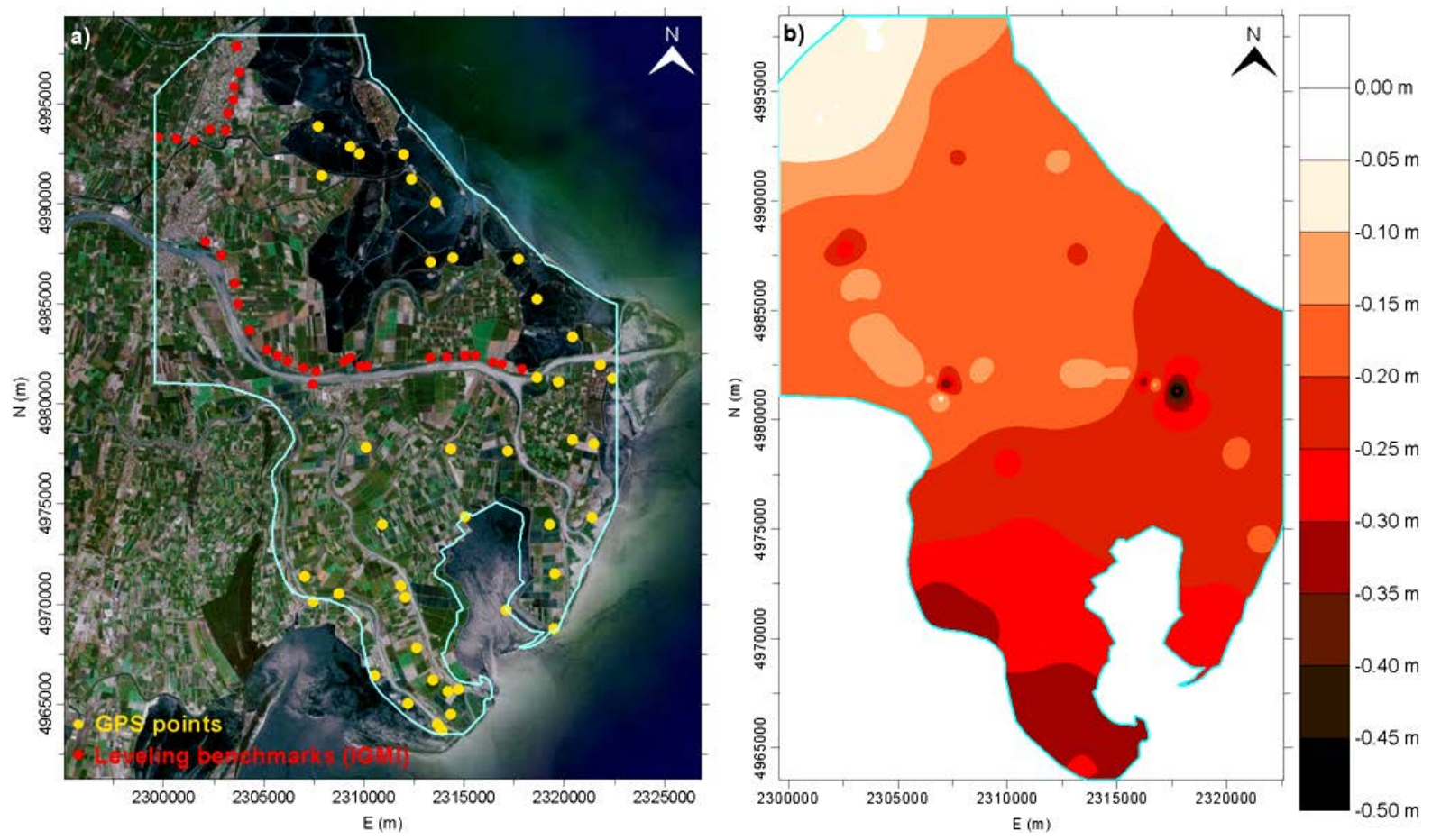

Figure 5. (a) Location of 32 leveling benchmarks and 43 GPS points measured in study area; (b) map of subsidence, 19832008, from 75 points calculated with IDW deterministic method (10 m grid size): only area within benchmarks was analysed. Maximum differences $(30-35 \mathrm{~cm})$ located in south-eastern part of study area. 
bordering the Emilia Romagna Region. These results were confirmed by comparisons with two leveling benchmarks at Goro and the forest of Mesola (Figure 1), measured in 1984, 1987, 1999 and 2005 with spirit leveling by the Emilia Romagna regional authorities [73]. Direct comparisons for the same period between measured subsidence on the two benchmarks and data extrapolated from the map of Figure 5(b) show differences of about $2 \mathrm{~mm}$, i.e., less than the precision of the method. The three leveling benchmarks in Emilia Romagna (Goro, Mesola, and the mouth of the Po di Goro—for the last, only vertical displacement value for 1999-2005 is available) close to that part of the Po Delta near the Veneto Region, showed no linear displacements between 1983 and 2008: the benchmarks provided values of about 18, 17 and $10 \mathrm{~mm} /$ year, measured in 1984-1987, 1987-1999 and 1999-2005, respectively.

Tosi et al. [2], merging various displacement measurements obtained from spirit leveling, DGPS, CGPS and SAR-based interferometry [74], also produced a map of land displacement rates in the period 1992-2002 which, in the Po Delta, provides vertical movements of about $10 \mathrm{~mm} /$ year. Baldi et al. [32], using the CGPS method, recently reported subsidence in the eastern part of the province of Ferrara near the Delta of about $6 \mathrm{~mm} / \mathrm{year}$ in 2006-2011, although their data only partially cover our study area. Thus, it seems realistic to adopt the same subsidence trend for our study area, with considerable vertical displacements in the 1980s, whereas they fell to almost half in the last period.

Figure 6 plots subsidence rates, together with tidal records from the Venice and Ravenna stations (from 1986 to 2013), as these are the stations nearest to the Po Delta with long-term sea level datasets. They show that the sea level has been rising for the last 27 years: with the isostatic and tectonic subsidence rates obtained in this
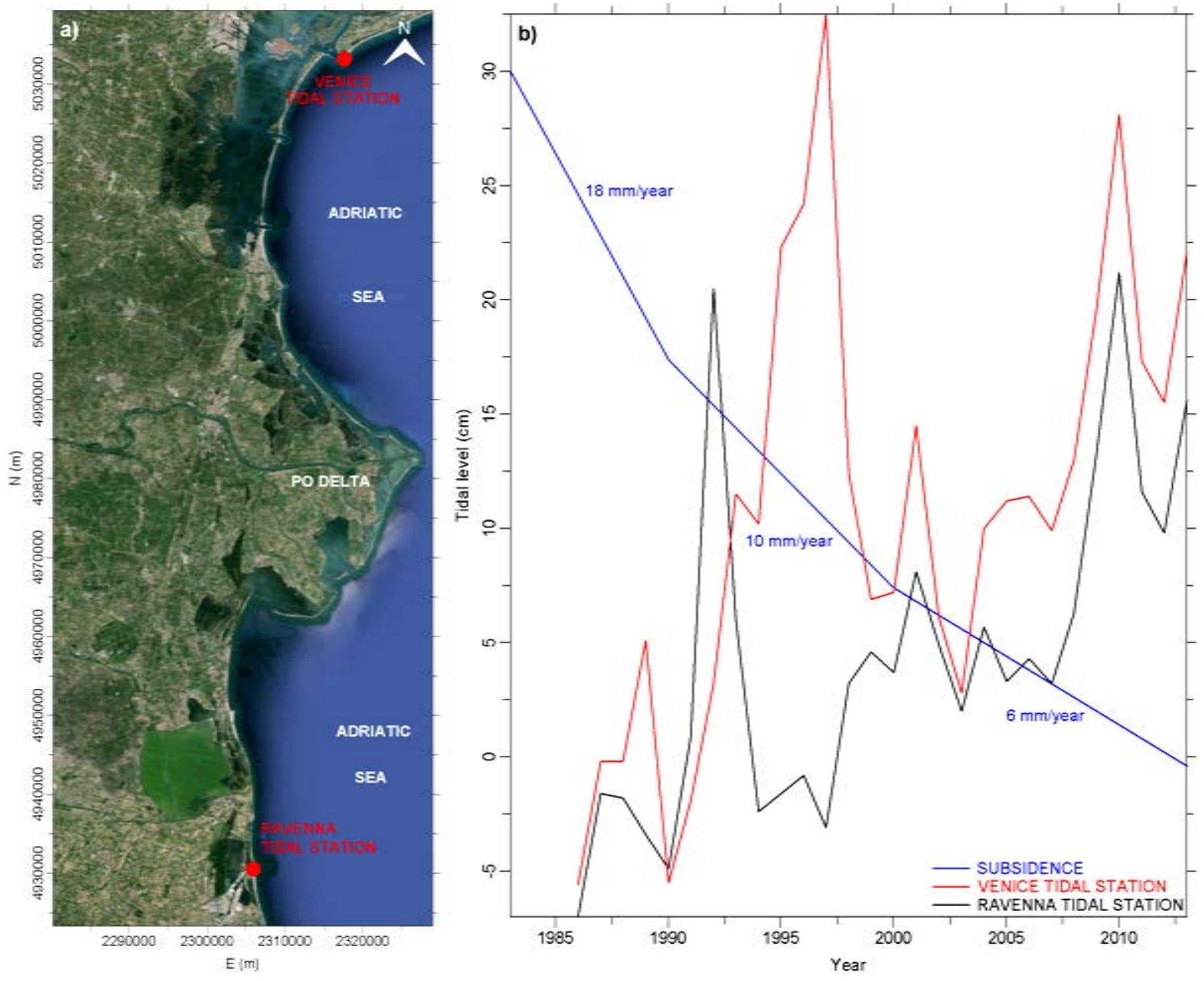

Figure 6. (a) Location of Ravenna and Venice tidal stations, with long-term data of sea level nearest to Po Delta area; (b) Plot of subsidence rates, with tidal records of Venice and Ravenna stations (1986-2013, data from www.mareografico.it). 
work, these values indicate the increased risk of flooding throughout the area.

The problem of sea level rise, both past and future, especially in coastal areas with subsidence which enhance the risk of flooding still further, have been discussed by many authors [16]-[19] [27] [75]-[76]. Lambeck et al. [29] provide a vertical displacement scenario for the Delta in the year 2100, considering the contribution of isostasy, tectonics and relative sea level rise calculated in 2010, ranging from $315 \mathrm{~mm}$ to $1535 \mathrm{~mm}$ for the lowimpact ([78]; +180 mm sea level rise) and high-impact scenarios ([79]; +1400 mm sea level rise), respectively. However, these values do not include the contribution of recent soil compaction and fluid withdrawal (gas and water). The latter data, extrapolating the trend of Figure 6 until 2100 for artificial subsidence, give new values of 370 and $1590 \mathrm{~mm}$, respectively. In these conditions, Syvitski et al. [58], who place the Po Delta in the highrisk group of “virtually no aggradation and/or very high accelerated compaction”, estimate an increase of 50\% in the risk of flooding during the $21^{\text {st }}$ century if global sea level continues to rise rapidly. The results of this work do seem to confirm this risk value and indicate that, due to the ongoing increase in storm events, reinforcement of all kinds of flood defenses will have to be examined carefully.

\section{Conclusions}

Vertical displacements in Po Delta area of the Veneto Region were estimated for the 1983-2008 period according to a procedure based on GPS measurements of archival leveling benchmarks and integration with recent spirit leveling values. Due to the uncertain elevations of "historical" benchmarks, a method of geoid height checking was applied. Eight models were compared in a study area near the Po Delta. Equation (5) provides the best results here; in areas with different morphology, documented gravimetric anomalies, etc., the equation of local geoid modeling may be different. Thus, after ellipsoid elevations had been transformed into orthometric ones and inhomogeneous benchmarks had been removed or corrected, vertical displacement values could be obtained by comparing homogeneous elevations surveyed over various periods of time.

The above method is particularly efficient as regards time and costs (GPS measurements are faster) than spirit leveling. Full integration with archival orthometric elevations of benchmarks can also be made, recovering useful historical data. Monitoring of the area can then be performed simply with periodical GPS surveys on the same benchmark, which provide vertical displacements for comparison with homogeneous ellipsoid elevations.

The application of this method to the Po Delta yielded subsidence map for the period 1983-2008, interpolating 75 points. In the future, increasing benchmarks will better describe vertical movements in more detail, intercepting any other peaks of subsidence. The major vertical displacements measured in the southern part of the study area were confirmed by comparing the two leveling benchmarks of the Emilia Romagna Region, bordering the Delta. The integration of more recent data [2] [32] also indicates mean vertical subsidence of about 18 mm/year from 1983 to the early 1990s, 10 mm/year from then until the early years of the new century, and 6 $\mathrm{mm}$ /year the early 2000s to the present. These data confirm that artificial subsidence is still active, although the rate has decreased (with no linear trend) in the last decade. For this reason, monitoring is still necessary, especially considering the medium/long-term risk of flooding due to sea level rise.

\section{References}

[1] Avallone, A., Selvaggi, G., D’Anastasio, E., D’Agostino, N., Pietrantonio, G., Riguzzi, F., Serpelloni, E., Anzidei, M., Casula, G., Cecere, G., D’Ambrosio, C., De Martino, P., Devoti, R., Falco, L., Mattia, M., Rossi, M., Obrizzo, F., Tammaro, U. and Zarrilli, L. (2010) The RING Network: Improvements to a GPS Velocity Field in the Central Mediterranean. Annals of Geophisics, 53, 45-49.

[2] Tosi, L., Teatini, P., Strozzi, T., Carbognin, L., Brancolini, G. and Rizzetto, F. (2010) Ground Surface Dynamics in the Northern Adriatic Coastland over the Last Two Decades. Rendiconti Lincei. Scienze Fisiche e Naturali, 21, S115S129.

[3] Crespi, M., Marana, B., Sansò, F. and Sguerso, D. (1993) GPS Leveling and the Geoid. In: Adam, J., Ed., Proceedings of the 2nd International Seminar on GPS in Central Europe, Penc, 27-29 April 1993, 209-228.

[4] Yanalak, M. and Baykal, O. (2001) Transformation of Ellipsoid Heights to Local Leveling Heights. Journal of Surveying Engineering, 127, 90-103. http://dx.doi.org/10.1061/(ASCE)0733-9453(2001)127:3(90)

[5] Chandler, J.H. and Cooper, M. (1988) Monitoring the Development of Landslides Using Archival Photography and Analytical Photogrammetry. Land Miner Surveying Royal Institution of Chartered Surveyors, 6, 576-584.

[6] Chandler, J.H. and Cooper, M. (1988) The Extraction of Positional Data from Historical Photographs and Their Appli- 
cation in Geomorphology. The Photogrammetric Record, 13, 69-78. http://dx.doi.org/10.1111/j.1477-9730.1989.tb00647.x

[7] Walstra, J., Chandler, J.H., Dixon, N. and Dijkstra, T.A. (2004) Extracting Landslide Movements from Historical Aerial Photographs. In: Lacerda, W., Erlich, M., Fontoura, S.A.B. and Sayao, A.S.F., Eds., Landslides: Evaluation and Stabilization, Taylor \& Francis, London, 843-850.

[8] Chandler, J.H., Lane, S. and Walstra, J. (2007) Quantifying Landform Change. In: Fryer, J., Mitchell, H., Chandler, J.H., Eds., Applications of 3D Measurement from Images, Whittles Publishing, Dunbeath, 139-170.

[9] Baldi, P., Cenni, N., Fabris, M. and Zanutta, A. (2008) Kinematics of a Landslide Derived from Archival Photogrammetry and GPS Data. Geomorphology, 102, 435-444. http://dx.doi.org/10.1016/j.geomorph.2008.04.027

[10] Marsella, M., Baldi, P., Coltelli, M. and Fabris, M. (2012) The Morphological Evolution of the Sciara del Fuoco Since 1868: Reconstructing the Effusive Activity at Stromboli Volcano. Bulletin of Volcanology, 74, 231-248. http://dx.doi.org/10.1007/s00445-011-0516-6

[11] Achilli, V., Baldi, P., Baratin, L., Bonini, C., Ercolani, E., Gandolfi, S., Anzidei, M. and Riguzzi, F. (1998) Digital Photogrammetric Survey on the Island of Vulcano. Acta Vulcanologica, 10, 1-6.

[12] Pesci, A., Fabris, M., Conforti, D., Loddo, F., Baldi, P. and Anzidei, M. (2007) Integration of Ground-Based Laser Scanner and Aerial Digital Photogrammetry for Topographic Modelling of Vesuvio Volcano. Journal of Volcanology and Geothermal Research, 162, 123-138. http://dx.doi.org/10.1016/j.jvolgeores.2007.02.005

[13] Fabris, M., Baldi, P., Anzidei, M., Pesci, A., Bortoluzzi, G. and Aliani, S. (2010) High Resolution Topographic Model of Panarea Island by Fusion of Photogrammetric, Lidar and Bathymetric Digital Terrain Models. The Photogrammetric Record, 25, 382-401. http://dx.doi.org/10.1111/j.1477-9730.2010.00600.x

[14] Carminati, E., Martinelli, G. and Severi, P. (2003) Influence of Glacial Cycles and Tectonics on Natural Subsidence in the Po Plain (Northern Italy): Insights from 14C Ages. Geochemistry, Geophysiscs, Geosystem, 4, 1-14. http://dx.doi.org/10.1029/2002GC000481

[15] Antonioli, F., Anzidei, M., Auriemma, R., Gaddi, D., Furlani, S., Lambeck, K., Orrù, P., Solinas, E., Gaspari, A., Karinja, S., Kovačič, V. and Surace, L. (2007) Sea Level Change during Holocene from Sardinia and Northeastern Adriatic from Archaeological and Geomorphological Data. Quaternary Science Reviews, 26, 2463-2486. http://dx.doi.org/10.1016/j.quascirev.2007.06.022

[16] Stocchi, P., Girometti, L., Spada, G., Anzidei, M. and Colleoni, F. (2009) Post Glacial Readjustment, Sea Level Variations, Subsidence and Erosion along the Italian Coasts. Bollettino di Geofisica Teorica e Applicata, 50, 129-144.

[17] Ferranti, L., Antonioli, F., Anzidei, M., Monaco, C. and Stocchi, P. (2010) The Timescale and Spatial Extent of Vertical Tectonic Motions in Italy: Insights from Relative Sea-Level Changes Studies. Journal of the Virtual Explorer, 36, Paper 23. http://dx.doi.org/10.3809/jvirtex.2010.00255 http://virtualexplorer.com.au/article/2010/255/vertical-tectonic-motions-in-italy

[18] Anzidei, M., Antonioli, F., Benini, A., Lambeck, K., Sivan, D., Serpelloni, E. and Stocchi, P. (2011) Sea Level Change and Vertical Land Movements since the Last Two Millennia along the Coasts of Southwestern Turkey and Israel. Quaternary International, 232, 13-20. http://dx.doi.org/10.1016/j.quaint.2010.05.005

[19] Braitenberg, C., Mariani, P., Tunini, L., Grillo, B. and Nagy, I. (2011) Vertical Crustal Motions from Differential Tide Gauge Observations and Satellite Altimetry in Southern Italy. Journal of Geodynamics, 51, 233-244. http://dx.doi.org/10.1016/j.jog.2010.09.003

[20] Picotti, V. and Pazzaglia, F.J. (2008) A New Active Tectonic Model for the Construction of the Northern Apennines Mountain front Near Bologna (Italy). Journal of Geophysical Research, 113, 1-24. http://dx.doi.org/10.1029/2007JB005307

[21] Mantovani, E., Babbucci, D., Tamburelli, C. and Viti, M. (2009) A Review on the Driving Mechanism of the Tyrrhenian-Apennines System: Implications for the Present Seismotectonic Setting in the Central-Northern Apennines. Tectonophysics, 476, 22-40. http://dx.doi.org/10.1016/j.tecto.2008.10.032

[22] Arca, S. and Beretta, G.P. (1985) Prima sintesi geodetica-geologica sui movimenti verticali del suolo nell’Italia Settentrionale. Bollettino di Geodesia e Scienze Affini, 44, 125-156.

[23] Carminati, E. and Martinelli, G. (2002) Subsidence Rates in the Po Plain, Northern Italy: The Relative Impact of Natural and Anthropogenic Causation. Engineering Geology, 66, 241-255. http://dx.doi.org/10.1016/S0013-7952(02)00031-5

[24] Teatini, P., Ferronato, M., Gambolati, G., Bertoni, W. and Gonella, M. (2005) A Century of Land Subsidence in Ravenna Italy. Environmental Geology, 47, 831-846. http://dx.doi.org/10.1007/s00254-004-1215-9

[25] Dal Cin, R. (1983) I litorali del delta del Po e alle foci dell’Adige e del Brenta: Caratteri tessiturali e dispersione dei sedimenti cause dell'arretramento e previsioni sull'evoluzione futura. Bollettino della Società Geologica Italiana, 102, 9-56. 
[26] Carbognin, L. and Tosi, L. (2002) Interaction between Climate Changes, Eustacy and Land Subsidence in the North Adriatic Region, Italy. Marine Ecology, 23, 38-50. http://dx.doi.org/10.1111/j.1439-0485.2002.tb00006.x

[27] Antonioli, F. and Silenzi, F. (2007) Variazioni relative del livello del mare e vulnerabilità delle pianure costiere italiane. Quaderni della Società Geologica Italiana, 2, 1-29.

[28] Tosi, L., Teatini, P., Carbognin, L. and Brancolini, G. (2009) Using High Resolution Data to Reveal Depth-Dependent Mechanisms that Drive Land Subsidence: The Venice Coast, Italy. Tectonophysics, 474, 271-284. http://dx.doi.org/10.1016/j.tecto.2009.02.026

[29] Lambeck, K., Antonioli, F., Anzidei, M., Ferranti, L., Leoni, G., Scicchitano, G. and Silenzi, S. (2011) Sea Level Change along the Italian Coast during the Holocene and Projections for the Future. Quaternary International, 232, 250-257. http://dx.doi.org/10.1016/j.quaint.2010.04.026

[30] Carbognin, L., Teatini, P. and Tosi, L. (2004) Eustacy and Land Subsidence in the Venice Lagoon at the Beginning of the New Millennium. Journal of Marine Systems, 51, 345-353. http://dx.doi.org/10.1016/j.jmarsys.2004.05.021

[31] Bock, Y., Wdowinski, S., Ferretti, A., Novali, F. and Fumagalli, A. (2012) Recent Subsidence of the Venice Lagoon from Continuous GPS and Interferometric Synthetic Aperture Radar. Geochemistry, Geophysics, Geosystems, 13, 1-13. http://dx.doi.org/10.1029/2011GC003976 http://onlinelibrary.wiley.com/doi/10.1029/2011GC003976/abstract

[32] Baldi, P., Casula, G., Cenni, N., Loddo, F., Pesci, A. and Bacchetti, M. (2011) Vertical and Horizontal Crustal Movements in Central and Northern Italy. Bollettino della Società Geologica Italiana (Italian Journal of Geosciences), 52, 667-685.

[33] Ericson, J.P., Vörösmarty, C.J., Dingman, S.L., Ward, L.G. and Meybeck, M. (2006) Effective Sea Level Rise and Deltas: Causes of Change and Human Dimension Implication. Global and Planetary Change, 50, 63-82. http://dx.doi.org/10.1016/j.gloplacha.2005.07.004

[34] Jeftic, L., Keckes, S. and Pernetta, J.C. (1996) Implications of Future Climatic Changes for the Mediterranean Coastal Region. In: Jeftic, L., Keckes, S. and Pernetta, J.C., Eds., Climate Change and the Mediterranean, Vol. 2, Edward Arnold, London, 1-25.

[35] Simeoni, U. and Corbau, C. (2008) A Review of the Delta Po Evolution (Italy) Related to Climatic Changes and Human Impacts. Geomorphology, 107, 64-71. http://dx.doi.org/10.1016/j.geomorph.2008.11.004

[36] Teatini, P., Ferronato, M., Gambolati, G. and Gonella, M. (2006) Groundwater Pumping and Land Subsidence in the Emilia-Romagna Coastland, Italy: Modeling the Past Occurrence and the Future Trend. Water Resources Research, 42, 1-19. http://dx.doi.org/10.1029/2005WR004242 http://onlinelibrary.wiley.com/doi/10.1029/2005WR004242/abstract

[37] Colombo, P. and Tosini, L. (2010) Sessant’anni di bonifica nel delta del Po. Papergraf S.p.a., Padova.

[38] Zambon, M. (1967) Abbassamento del Suolo per Estrazioni di Acqua e Gas: Deduzioni ed Indirizzi Logicamente Conseguenti per la Sistemazione del Delta del Fiume Po. Proceedings of the 23rd National Conference on "Bonifiche", Rome, 20 May 1967, 345-370.

[39] Caputo, M., Pieri, L. and Unguendoli, M. (1970) Geometric Investigation of the Subsidence in the Po Delta. Bollettino di Geofisica Teorica e Applicata, 47, 187-207.

[40] Bondesan, M. and Simeoni, U. (1983) Dinamica e analisi morfologica statistica dei litorali del delta del Po e alle foci dell'Adige e del Brenta. Memorie di Scienze Geologiche, 36, 1-48.

[41] Bondesan, M., Minarelli, A. and Russo, P. (1990) Analisi dei movimenti verticali del suolo avvenuti nel periodo 1970-1978 lungo l'asta del Po ad est di Polesella e nel Delta. PO AcquAgricolturAmbiente. L'alveo e il delta, 2, 385-407.

[42] Bondesan, M., Favero, V. and Vinals, M.J. (1995) New Evidence on the Evolution of the Po-Delta Coastal Plain during the Holocene. Quaternary International, 29-30, 105-110. http://dx.doi.org/10.1016/1040-6182(95)00012-8

[43] Brighenti, G., Macini, P. and Mesini, E. (1998) Subsidence in Northern Italy: Compaction Measurements of Water-Gas Bearing Formations. Proceedings of the 8th IAEG Congress, Vancouver, 21-25 September 1998, 207-214.

[44] Schrefler, B.A., Ricceri, G., Achilli, V., Menin, A. and Salomoni, V.A. (2009) Ground Displacement Data around the City of Ravenna Do Not Support Uplifting Venice by Water Injection. Terra Nova, 21, 144-150. http://dx.doi.org/10.1111/j.1365-3121.2009.00867.x

[45] Salvioni, G. (1957) I movimenti del suolo nell’Italia Centro-Settentrionale. Bollettino di Geodesia e Scienze Affini, 16, 325-366.

[46] Caputo, M., Folloni, G., Gubellini, A., Pieri, L. and Unguendoli, M. (1972) Survey and Geometric Analysis of the Phenomena of Subsidence in the Region of Venice and Its Hinterland. Rivista Italiana di Geofisica, 21, 19-26.

[47] Borgia, G., Brighenti, G. and Vitali, D. (1982) La Coltivazione dei Pozzi Metaniferi del Bacino Polesano e Ferrarese. 
Esame Critico della Vicenda. Inarcos, Georise e Territorio, 425, 13-23.

[48] Barbarella, M., Pieri, L. and Russo, P. (1990) Studio dell'abbassamento del suolo nel territorio bolognese mediante livellazioni ripetute: Analisi dei movimenti e considerazioni statistiche. Inarcos, 506, 1-19.

[49] Bondesan, M., Gatti, M. and Russo, P. (1997) Movimenti verticali del suolo nella Pianura Padana orientale desumibili dai dati I.G.M. fino a tutto il 1990. Bollettino di Geodesia e Scienze Affini, 56, 141-172.

[50] Bitelli, G., Bonsignore, F. and Unguendoli, M. (2000) Leveling and GPS Networks to Monitor Ground Subsidence in the Southern Po Valley. Journal of Geodynamics, 30, 355-369. http://dx.doi.org/10.1016/S0264-3707(99)00071-X

[51] Macini, P., Mesini, E., Salomoni, V.A. and Schrefler, B.A. (2006) Casing Influence While Measuring in Situ Reservoir Compaction. Journal of Petroleum Science and Engineering, 50, 40-54.

[52] Menin, A., Salomoni, V.A., Santagiuliana, R., Simoni, L., Gens, A. and Schrefler, B. (2008) A Mechanism Contributing to Subsidence above Gas Reservoirs and Its Application to a Case Study. International Journal for Computational Methods in Engineering Science and Mechanics, 9, 270-287. http://dx.doi.org/10.1080/15502280802225234

[53] Baldi, P., Casula, G., Cenni, N., Loddo, F. and Pesci, A. (2009) GPS-Based Monitoring of Land Subsidence in the Po Plain (Northern Italy). Earth and Planetary Science Letters, 288, 204-212. http://dx.doi.org/10.1016/j.epsl.2009.09.023

[54] Schrefler, B.A., Ricceri, G., Achilli, V., Fabris, M. and Laloui, L. (2009) Actual Problems in the Study of Soil Dynamics of the Upper Adriatic Sea. Rendiconti online della Società Geologica Italiana, 9, 63-66.

[55] Gambolati, G., Teatini, P., Tomasi, L. and Gonella, M. (1999) Coastline Regression of the Romagna Region, Italy, Due to Natural and Anthropogenic Land Subsidence and Sea Level Rise. Water Resources Research, 35, 163-184. http://dx.doi.org/10.1029/1998WR900031

[56] Gambolati, G., Teatini, P., Baú, D. and Ferronato, M. (2000) Importance of Poroelastic Coupling in Dynamically Active Aquifers of the Po River Basin, Italy. Water Resources Research, 36, 2443-2459. http://dx.doi.org/10.1029/2000WR900127

[57] Gornitz, V. (1995) Sea-Level Rise: A Review of Recent Past and Near-Future Trends. Earth Surface Processes and Landforms, 20, 7-20. http://dx.doi.org/10.1002/esp.3290200103

[58] Syvitski, J.P.M., Kettner, A.J., Overeem, I., Hutton, E.W.H., Hannon, M.T., Brakenridge, G.R., Day, J., Vörösmarty, C., Saito, Y., Giosan, L. and Nicholls, R.J. (2009) Sinking Deltas Due to Human Activities. Nature Geoscience, 2, 681686. http://dx.doi.org/10.1038/ngeo629

[59] Strange, W. (1981) The Impact of Refraction Correction s on Leveling Interpretations in Southern California. Journal of Geophysical Research Letters, 86, 2809-2824. http://dx.doi.org/10.1029/JB086iB04p02809

[60] Stein, R. (1981) Discrimination of Tectonic Displacement from Slope-Dependent Errors in Geodetic Leveling from Southern California, 1953-1979. In: Simpson, D. and Richards, P., Eds., Earthquake Prediction: An International Review, AGU Maurice Ewing Series, Vol. 4, American Geophysical Union, Washington DC, 441-456.

[61] Fabris, M., Achilli, V., Bragagnolo, D., De Gennaro, M., Mavaracchio, C., Menin, A., Ricceri, G. and Zampieri, A. (2008) Fotogrammetria d'archivio e metodologie geodetiche per la definizione delle variazioni morfologiche del delta del Po. Proceedings of the SIFET Congress "La Topografia per le Opere di Ingegneria: Metodi, Strumenti ed Applicazioni”, 18-20 June 2008, Sorrento, 80-85.

[62] Psimoulis, P., Ghilardi, M., Fouache, E. and Stiros, S. (2007) Subsidence and Evolution of the Thessaloniki Plain, Greece, Based on Historical Leveling and GPS Data. Engineering Geology, 90, 55-70. http://dx.doi.org/10.1016/j.enggeo.2006.12.001

[63] Cocard, M., Kahle, H.G., Peter, Y., Veis, G., Felekis, S., Paradissis, D. and Billiris, H. (1999) New Constraints on the Rapid Crustal Motion of the Aegean Region: Recent Results Inferred from GPS Measurements (1993-1998) across the Hellenic Arc, Greece. Earth and Planetary Science Letters, 172, 39-47. http://dx.doi.org/10.1016/S0012-821X(99)00185-5

[64] Kakkuri, J. (1986) Newest Results Obtained in Studying the Fennoscandian Land Uplift Phenomenon. Tectonophysics, 130, 327-331. http://dx.doi.org/10.1016/0040-1951(86)90122-8

[65] Norinelli, A., Cassano, E. and Fichera, R. (1988) Dati geofisici dell'area patavino-veneziana. Atti dell' Istituto Veneto di Scienze, Lettere ed Arti, 146, 201-224.

[66] Aizerman, M.A., Braverman, E.M. and Rozonoer, L.I. (1964) Theoretical Foundations of the Potential Function Method in Pattern Recognition Learning. Automation and Remote Control, 25, 821-837.

[67] Bashkirov, O.K., Braverman, E.M. and Muchnik, I.B. (1964) Potential Function Algorithms for Pattern Recognition Learning Machines. Automation and Remote Control, 25, 629-631.

[68] Powell, M.J.D. (1987) Radial Basis Functions for Multivariable Interpolation: A Review. In: Mason, J.C. and Cox, M.G., Eds., Algorithms for Approximation, Carendon Press, Oxford, 143-167.

[69] Cressie, N. (1990) The Origins of Kriging. Mathematical Geology, 22, 239-252. 
http://dx.doi.org/10.1007/BF00889887

[70] Bartier, P.M. and Keller, C.P. (1996) Multivariate Interpolation to Incorporate Thematic Surface Data Using Inverse Distance Weighting (IDW). Computers \& Geosciences, 22, 795-799. http://dx.doi.org/10.1016/0098-3004(96)00021-0

[71] Lin, G.F. and Chen, L.H. (2004) A Spatial Interpolation Method Based on Radial Basis Function Networks Incorporating a Semivariogram Model. Journal of Hydrology, 288, 288-298. http://dx.doi.org/10.1016/j.jhydrol.2003.10.008

[72] Lu, G.Y. and Wong, D.W. (2008) An Adaptive Inverse-Distance Weighting Spatial Interpolation Technique. Computers \& Geosciences, 34, 1044-1055. http://dx.doi.org/10.1016/j.cageo.2007.07.010

[73] Arpa (2006) Rilievo della subsidenza nella pianura emiliano-romagnola. In: II stralcio di attività finalizzate alla misura di una rete di livellazione a supporto dell'analisi interferometria, Relazione finale, Arpa-Ingegneria Ambientale, Regione Emilia-Romagna, Bologna, 1-37.

[74] Teatini, P., Tosi, L., Strozzi, T., Carbognin, L., Wegmuller, U. and Rizzetto, F. (2005) Mapping Regional Land Displacements in the Venice Coastland by an Integrated Monitoring System. Remote Sensing of Environment, 98, 403-413. http://dx.doi.org/10.1016/j.rse.2005.08.002

[75] Lambeck, K. (1995) Late Pleistocene and Holocene Sea Level Change in Greece and South-Western Turkey: A Separation of Eustatic, Isostatic and Tectonic Contributions. Geophysical Journal International, 122, 1022-1044. http://dx.doi.org/10.1111/j.1365-246X.1995.tb06853.x

[76] Lambeck, K., Woodroffe, C.D., Antonioli, F., Anzidei, M., Gehrels, W.R., Laborel, J. and Wright, A. (2010) Paleoenvironmental Records, Geophysical Modeling, and Reconstruction of Sea-Level Trends and Variability on Centennial and Longer Timescales. In: Church, J.A., Woodworth, P.L., Aarup, T. and Wilson, W.S., Eds., Understanding Sea Level Rise and Variability, Blackwell Publishing, Oxford, 61-121. http://dx.doi.org/10.1002/9781444323276.ch4

[77] Zecca, A. and Chiari, L. (2012) Lower Bounds to Future Sea-Level Rise. Global and Planetary Change, 98-99, 1-5. http://dx.doi.org/10.1016/j.gloplacha.2012.08.002

[78] IPCC (2007) Summary for Policymakers. Contribution of Working Group I to the Fourth Assessment Report of the Intergovernmental Panel on Climate Change. In: Solomon, S., Qin, D., Manning, M., Chen, Z., Marquis, M., Averyt, K.B., Tignor, M. and Miller, H.L., Eds., Climate Change 2007: The Physical Science Basis, Cambridge University Press, Cambridge, United Kingdom and New York.

[79] Rahmstorf, S. (2007) A Semi-Empirical Approach to Projecting Future Sea-Level Rise. Science, 315, 368-370. http://dx.doi.org/10.1126/science.1135456 